\title{
EATING PRACTICES, NUTRITIONAL STATUS AND CONSTIPATION IN PATIENTS WITH RETT SYNDROME
}

\author{
Flavia SCHWARTZMAN¹, Márcia Regina VíTOLO², José Salomão SCHWARTZMAN³ and \\ Mauro Batista de MORAIS ${ }^{4}$
}

\begin{abstract}
Background - Disturbance in chewing, swallowing and digestive motility may predispose to feeding and nutritional abnormalities in patients with Rett syndrome. Objective - To evaluate the dietary habits, nutritional status and the prevalence of constipation in patients with classical Rett syndrome. Methods - Twenty seven female patients between the ages of 2.6 and 21.8 years were studied. The following parameters were evaluated: food register, weight, height and intestinal movement characteristics. Weight and height were compared with the National Center for Health Statistics standards. Results - The inability to ingest solid foods was observed in $80.8 \%$ of the patients. A height-to-age deficit was observed in 13 (48.1\%) of the girls, being more intense in patients at stage IV. Weight-for-height deficit was found in $10(37.0 \%)$ patients, $15(55.6 \%)$ showed normal weight and $2(7.4 \%)$ were overweight for their height. The median ingestion of energy, according to weight-for-height, was equal to $106.6 \%$. Insufficient iron ingestion was observed in $63.0 \%$ and insufficient calcium in $55.6 \%$ of the patients. Constipation was verified in $74.1 \%$ of the patients and did not show a relationship with the quantity of fiber in the diet. Conclusion - Various nutritional problems, as well as, intestinal constipation were observed in these patients with Rett syndrome, and they must be considered in the multidisciplinary therapeutic planning of these individuals.
\end{abstract}

HEADINGS - Rett syndrome. Nutritional status. Deglutition disorders. Constipation.

\section{INTRODUCTION}

Rett syndrome (RS) is a neurological disease with unknown etiology initially described by Dr. Andreas Rett, in 1966. The classic form of the disease affects only female children ${ }^{(21)}$.

Recently, a mutation in gene $\mathrm{MeCP} 2$ has been identified in $80 \%$ of the patients ${ }^{(21,22)}$. The prevalence of the disease is $1: 12.000$ to $1: 22.000$ live births. It affects girls born from a normal and term gestation. Post natal period, as well as the first months of life, is apparently normal in these girls. The onset of the disease occurs between 6 and 18 months of life and stagnation of the neuropsychomotor development characterizes the initial phase of the disease. Other characteristics of RS are: acquired microencephaly, stereotyped movements and loss of purposeful hand use, respiratory problems, epilepsy, sensorial and motor deficits, nutritional deficits and scoliosis ${ }^{(7,21,22,28)}$.

Chewing and swallowing problems, as well as gastroesophagic reflux, are frequent in this population ${ }^{(2,13,14,20)}$ and predispose them to various nutrition and feeding problems. Oral motor dysfunction and inability to selffeed have been described as factors that significantly affect the energy intake of children with cerebral palsy, which can lead to growth impairment ${ }^{(14,20,29)}$.

Linear growth retardation and poor weight gain are common in girls with $\mathrm{RS}^{(6,15,29)}$, although some may have adequate weight and, even, be overweight ${ }^{(14)}$. The causes of the growth and weight deficit in RS are not yet very clear, but it seems to be multifactor. Some suggest it is part of the disease, while others suggest it is secondary to different factors, such as brain-based trophic influence, inadequate dietary intakes, increased energy expenditure, malabsorption or metabolic disorders ${ }^{(13,15,20)}$.

Chronic constipation is prevalent in patients with chronic non-progressive encephalopathy ${ }^{(25)}$ and constitutes a serious problem that jeopardizes the quality of their lives even more. According to the few studies available ${ }^{(1,19)}$, the prevalence of constipation seems to be high in individuals with RS and may be due to medication, sedentary life and low intake of solid foods and liquids ${ }^{(4,25)}$.

Because information on the nutritional aspects and the intestinal habits in RS are scarce, this study aimed at assessing the feeding characteristics, nutritional status and the prevalence of constipation in children with RS.

\footnotetext{
Pediatric Gastroenterology Discipline and Post Graduation Course on Nutrition of the Federal University of São Paulo, Paulista School of Medicine (UNIFESP-EPM). 1 Post Graduation Course on Nutrition, Federal University of São Paulo, Paulista School of Medicine (UNIFESP-EPM), São Paulo, SP, Brasil; ${ }^{2}$ Department of Public Health, Federal Faculty of Medical Sciences, Porto Alegre, RS, Brasil; ${ }^{3}$ Post Graduation Program on Development Disorders, Mackenzie Presbyterian University, São Paulo, SP, Brasil; ${ }^{4}$ Pediatric Gastroenterology Discipline, Federal University of São Paulo, UNIFESP-EPM.

Correspondence: Prof. Mauro Batista de Morais - Rua Pedro de Toledo, 441 - 04039-031 - São Paulo, SP, Brasil. E-mail: mbmorais@osite.com.br
} 


\section{METHODS}

\section{Study population}

All the 27 patients with the classic Rett syndrome that have been invited to participate were included in this descriptive and transversal study. The invitation to the families was made by the neurological pediatricians of São Paulo and the Brazilian Association of Rett Syndrome (Abre-te/SP). All participants agreed to take part in the study.

Confirmation of the diagnostic disease and classification of RS were performed by neuropediatricians, based on the criteria modified $^{(28)}$ by HAGBERG et al. ${ }^{(7)}$.

Pubertal development was classified according to TANNER pubertal stages ${ }^{(27)}$. Based on the assessment of the sexual development of the patients using Tanner's stages of pubertal development and on the occurrence of menarche, the girls were classified into pre-pubertal: those with breast development in stage M1; pubertal: girls who presented breast development in stage M2 or above, but not yet menarche; and post-menarche: girls who had already had their first menstrual period.

The study was approved by the Ethical Research Committee of the Federal University of São Paulo - "Escola Paulista de Medicina" (UNIFESP-EPM), São Paulo, SP, Brazil. The parents or guardians gave their written consent.

\section{Assessment of feeding practices related to oral motor dysfunctions}

A questionnaire about current feeding practices, presence of chewing and swallowing problems, feeding skills and acceptance of some foods, according to their consistency and texture, was developed and applied to the parents. The following criteria were used to classify foods/liquids consumed by the patients:

1. Thin liquids: water, juice, plain milk; 2. Thick liquids: yogurts and smoothies; 3. Smooth pureed food: semi solid consistency without lumps such as puddings, liquefied foods such as smoothies with cereals and soups; 4. Lumpy pureed foods: pureed foods smashed with fork or strained; 5. Solids easy to chew: pieces of non-fibrous foods, like breads, bagels, pasta, potato and well cooked vegetables: 6 . Solid foods: fibrous foods, in pieces, that require triturating, such as large pieces of red meat, apple, raw carrot and coconut.

\section{Assessment of food intake}

Food intake was assessed through a 3 day 24 hour diet recall ${ }^{(5)}$. Two days of the week and 1 on the weekend were analyzed. All parents were taught about how to fill out the questionnaire. When the complete questionnaire was delivered to the dietitian, food replicas were shown to parents, in order to confirm the amount eaten.

Food intake and diet adequacy were calculated for energy, protein, lipids, carbohydrate, iron, calcium, vitamins A and $\mathrm{C}$ and fiber. The software "Programa de Apoio à Nutrição" (Nutrition Support Program), version 2.5, developed by the Information Technology Center on Health of the UNIFESP$\mathrm{EPM}^{(3)}$, the "Tabela para Avaliação de Consumo Alimentar em Medidas Caseiras" (Table to Assess Food Intake in Household
Measures) $)^{(18)}$, as well as, label information were used to calculate energy, macro and micronutrients amounts. Fiber intake was analyzed using a table that presented the amount of fiber in food determined by the method by the Association of Official Analytical Chemists (AOAC) which provides the total amount of fiber ${ }^{(23)}$.

Energy adequacy was expressed according to energy recommendation based on 1 . Body weight, 2. Expected weight for current height, and 3. Chronological age ${ }^{(20)}$. Energy intake was considered adequate when intake was $100 \%$ or above the recommended allowance.

Macronutrients, vitamins $\mathrm{A}$ and $\mathrm{C}$ and iron were calculated based on the Recommended Dietary Allowances ${ }^{(17)}$. Intake was considered adequate when $80 \%$ or more of the recommended allowances were $\operatorname{met}^{(1)}$, according to age and pubertal development. Thus, for the pre-pubertal girls, the recommended energy, macro and micronutrient allowances correspondent to their age group were used. For pubertal girls who had not yet had the menarche, the allowances used were the ones for the age group 11 to 14 and, for post menarche girls, regardless of their age, the recommended values used were the ones for the age group 15 to 18 years old. For calcium, the Dietary Reference Intakes ${ }^{(31)}$ were used, considering the pubertal development, as explained above. The amount of fiber in the diet was compared to the minimum recommended allowance of the American Health Foundation, that is, age (in years) plus $5 \mathrm{~g}^{(34)}$.

\section{Anthropometric assessment}

Anthropometric assessment included measurements of height and weight. Height and weight measurements were obtained according to JELLIFFE ${ }^{(9)}$ recommendations. Patients who could not stand were weighed in their parents' arms and the parents' weight was subtracted from the total. For all children, weight was measured to the nearest $0.1 \mathrm{~kg}$ on a standard beam scale. Subjects who were unable to stand, but who had only mild scoliosis or contractures, were placed supine on a firm surface and had their height measured by a recumbent stadiometer. For those girls with severe scoliosis, contractures or spasticity, knee height was used as alternative anthropometric measure. Knee height was measured following the method described by STEVENSON ${ }^{(24)}$. Based on the equation proposed by him (shown bellow), reliable alternatives to recumbent length could be obtained.

Estimated stature $(\mathrm{cm})=(2.69 \times$ knee height $)+24.2$.

In order to classify the nutritional status of the patients, their pubertal development ${ }^{(33)}$ was taken into consideration. Pre-pubertal girls were classified according to $\mathrm{Z}$ scores for height-for-age and weight-for-height, using as reference, the $\mathrm{Z}$ score curves for the US population established by the National Center for Health Statistics (NCHS) and Center for Disease Control and Prevention $^{(33)}$. The cut-off points were -2.0 and +2.0 standarddeviations, for weight deficit and overweight, respectively ${ }^{(33)}$.

Height of the pubertal and post-menarche girls was assessed using height-for-age $\mathrm{Z}$ score, also using the -2.0 and +2.0 cut-off points. Weight assessment of these girls was performed using Body Mass Index (BMI). BMI was interpreted according to the reference percentiles recommended by $\mathrm{WHO}^{(33)}$ and published 
by MUST et al. ${ }^{(16)}$. Values bellow $5^{\text {th }}$ percentile were considered indicators of weight deficit, and values above the $85^{\text {th }}$ percentile were considered indicators of overweight ${ }^{(31)}$.

\section{Assessment of intestinal habit}

Intestinal habit of the patients was assessed through a questionnaire applied to the parents about presence of pain, difficulty or fear to evacuate, consistency and format of feces, frequency of evacuation and treatment for the constipation, if there was any.

Patients were considered to have chronic constipation when they evacuated hard feces, with pain or difficulty, with or without an increase in the interval between evacuations ${ }^{(12)}$.

\section{Hemoglobin determination}

Hemoglobin concentration was determined using a portable photometer (HemoCue, Angelholm, Sweden) and a blood sample collected by thumb prick. Blood was not collected fasting.

The diagnosis of anemia was established according to the cutt-off points suggested by the World Health Organization ${ }^{(32)}$.

\section{Statistical analysis}

For statistical analysis, the software Jandel Sigma Stat for Windows (SPSS Inc, Chicago, IL, USA) was used. Differences were considered statistically significant for probability levels $P<0.05$. Statistical tests are presented together with the results.

\section{RESULTS}

The age of the patients $(n=27)$ varied from 2.6 to 21.8 years. Mean (standard-deviation) birth weight and height were $2967 \pm$ 585 grams and $47.6 \pm 2.1$ centimeters, respectively. As far as their pubertal developmental, 11 (40.8\%) were pre-pubertal, $8(29.6 \%)$ pubertal and $8(29.6 \%)$ had already presented menarche.

Out of the total girls, $6(22.2 \%)$ walked independently, $3(11.1 \%)$ walked with help, $16(59.3 \%)$ remained seated the whole time and $2(7.4 \%)$ remained lied down. Sixteen $(59.3 \%)$ had scoliosis, $18(69.2 \%)$ seizures and $22(84.6 \%)$ were on some type of medication at the time of the study.

Regarding the stage of the disease, $15(55.6 \%)$ were on Stage III and $12(44.4 \%)$ on Stage IV. Twenty-two (81.5\%) of the patients had already been hospitalized (number of hospitalizations $=3.3 \pm 3.8$ ).

Only one patient (3.7\%) was able to feed herself independently, $1(3.7 \%)$ needed some help, and the remaining 25 (92.6\%) were completely dependent to eat with 1 patient (3.7\%) undergoing gastrostomy. When questioned about presence of chewing and swallowing difficulties, six parents $(15.4 \%)$ answered that their daughters did not have these kinds of problems, although none of these girls was able to eat solid foods.

Out of the 26 patients that did not have a gastrostomy, $21(80.8 \%)$ were not able to eat solid foods, $12(46.2 \%)$ were not able to eat solids easy to chew, and $5(19.2 \%)$ had difficulties to eat/drink thin liquids. Despite the difficulties reported, only $9(40.9 \%)$ of these 22 patients were undergoing feeding therapy at the time of the study. In addition to that,
$7(31.8 \%)$ had never gone through any evaluation with a speech therapist.

Height-for-age deficit ( $\mathrm{Z}$ score $<-2.0$ standard-deviation) was observed in 13 patients (48.1\%). Regarding weight-for-height, 3 $(27.3 \%)$ out of the 11 pre-pubertal girls presented weight deficit; $7(63.6 \%)$ presented normal weight-for-height; and $1(9.1 \%)$ was overweight. Concerning the 16 pubertal and post-menarche patients, 7 (43.8\%) had weight deficit; $8(50.0 \%)$ had normal weight, and $1(6.3 \%)$ was overweight. For the total sample, 10 patients $(37.0 \%)$ presented weight-for-height deficit; $15(55.6 \%)$ were eutrophic, and 2 (7.4\%) were overweight.

Table 1 presents patients' age, walking ability, presence of scoliosis and anthropometric indices according to the stage of RS. The median age of the girls in stage III ( 7.2 years) was significantly lower than the median age of the patients in stage IV (13.8 years). Although percentages of height-for-age and weightfor-height indices are higher in stage IV, the difference was not significant. On the other hand, the median height-for-age Z-score was statistically lower in stage IV, compared to stage III.

TABLE 1 . Age (median and 25 th and 75 th percentiles), ability to walk, presence of scoliosis and anthropometric indicators according to Rett syndrome stage

\begin{tabular}{lccc}
\hline & \multicolumn{3}{c}{ Stages } \\
\cline { 2 - 4 } & $\begin{array}{c}\text { III } \\
(\mathbf{n}=15)\end{array}$ & $\begin{array}{c}\text { IV } \\
(\mathbf{n}=12)\end{array}$ & $P$ \\
\hline Age (years) & 7.2 & 13.8 & $0.001^{1}$ \\
Inability to walk & $(4.8 ; 10.0)$ & $(10.7 ; 15.7)$ & \\
& 8 & 10 & $0.14^{2}$ \\
Presence of scoliosis & $(53.3 \%)$ & $(83.3 \%)$ & \\
Height deficit & 7 & 9 & $0.11^{2}$ \\
Weight deficit & $(46.7 \%)$ & $(75.0 \%)$ & \\
& 5 & 8 & $0.085^{2}$ \\
Height-for-age Z score & $(33.3 \%)$ & $(66.7 \%)$ & $0.199^{2}$ \\
& $(26.7 \%)$ & 6 & $0.019^{1}$ \\
\hline
\end{tabular}

Mann-Whitney test

Chi-Square or Fisher's exact tes

One patient was on ketogenic diet at the time of the study, as therapeutic for seizures. The diet record of this patient showed that the proteins contributed with $13.7 \%$, lipids with $82.5 \%$, and carbohydrates with $3.8 \%$ of the total calories. Regarding the remaining patients, proteins contributed from $11.1 \%$ to $19.4 \%$, lipids from $22.8 \%$ to $44.8 \%$, and carbohydrates from $40.1 \%$ to $64.5 \%$ of the total calories.

Medians (25th and 75th percentiles) of the energy intake percentile adequacies were: 1 . In relation to weight observed $=$ $111.0 \%(95.4 ; 153.1) ; 2$. In relation to expected weight for observed height $=106.6 \%(92.7 ; 123.4)$ and 3. In relation to energy need for chronological age $=72.3 \%(61.0 ; 84.6)$. Friedman's test for repeated measures together with multiple comparison Tukey's test showed that percentile adequacies in relation to the observed weight and in relation to the expected weight for height were not statistically different. In turn, these two estimates were greater than the percentile adequacy in relation to the chronological age, and the differences were statistically significant. 
TABLE 2. Median and 25th and 75th percentiles of the percentile adjustments of energy, proteins, calcium, iron vitamin C, vitamin A, and dietary fiber intake

\begin{tabular}{|c|c|c|c|}
\hline & \multicolumn{2}{|c|}{ Stages } & \multirow[b]{2}{*}{ Mann-Whitney test } \\
\hline & $\begin{array}{c}\text { III } \\
(\mathrm{n}=15)\end{array}$ & $\begin{array}{c}\text { IV } \\
(\mathrm{n}=12)\end{array}$ & \\
\hline$\%$ of energy adequacy for observed weight & $\begin{array}{c}110.7 \\
(85.2-125.2)\end{array}$ & $\begin{array}{c}115.9 \\
(95.6-172.2)\end{array}$ & 0.232 \\
\hline$\%$ of energy adequacy for ideal weight to the observed height & $\begin{array}{c}101.2 \\
(77.0-117.4)\end{array}$ & $\begin{array}{c}113.2 \\
(94.9-131.3)\end{array}$ & 0.180 \\
\hline$\%$ of energy adequacy for chronological age needs & $\begin{array}{c}77,9 \\
(63.4-85.5)\end{array}$ & $\begin{array}{c}71.8 \\
(58.4-81.7)\end{array}$ & 0.575 \\
\hline$\%$ of protein adequacy & $\begin{array}{c}170.8 \\
(141.9-212.1)\end{array}$ & $\begin{array}{c}130.7 \\
(106.8-146.7)\end{array}$ & 0.018 \\
\hline$\%$ of calcium adequacy & $\begin{array}{c}100,6 \\
(63.4-120.4)\end{array}$ & $\begin{array}{c}60.3 \\
(40.5-68.5)\end{array}$ & 0.008 \\
\hline$\%$ of iron adequacy & $\begin{array}{c}81.9 \\
(50.5-97.8)\end{array}$ & $\begin{array}{c}63.6 \\
(56.1-77.0)\end{array}$ & 0.421 \\
\hline$\%$ of vitamin $\mathrm{C}$ adequacy & $\begin{array}{c}149.3 \\
(72.5-343.5)\end{array}$ & $\begin{array}{c}264.7 \\
(160.4-320.8)\end{array}$ & 0.367 \\
\hline$\%$ of vitamin $\mathrm{A}$ adequacy & $\begin{array}{c}112.1 \\
(65.5-155.8)\end{array}$ & $\begin{array}{c}82.9 \\
(63.7-103.2)\end{array}$ & 0.421 \\
\hline$\%$ of fiber adequacy & $\begin{array}{c}63.2 \\
(36.0-127.5)\end{array}$ & $\begin{array}{c}65.1 \\
(49.1-84.7)\end{array}$ & 0.903 \\
\hline
\end{tabular}

Protein intake was above the minimum recommended allowance in 26 patients $(96.3 \%)$. Only one patient $(3.7 \%)$ had protein intake below $80 \%$ of the recommended value. Concerning calcium intake, 15 patients $(55.6 \%)$ had intakes $80 \%$ below the RDAs. Out of the 27 patients, $17(63.0 \%)$ did not meet $80 \%$ of the recommendation for iron. Inadequate vitamin $\mathrm{C}$ intake was observed in six patients $(22.2 \%)$. Fourteen patients $(51.9 \%)$ had inadequate intake of vitamin. Regarding fiber intake, 21 patients $(77.8 \%)$ presented intakes below the minimum amount recommended.

Table 2 shows energy, protein and other nutrients intake according to RS stages. The statistical analysis shows lower percentages of protein and calcium intake adequacy in patients on stage IV compared to patients on stage III.

The data obtained from the questionnaire about intestinal habit (Table 3 ) has shown that 20 patients $(74.1 \%)$ presented

TABLE 3. Features of intestinal habit and characterization of constipation in Rett syndrome

\begin{tabular}{|c|c|c|c|c|c|c|}
\hline & \multicolumn{2}{|c|}{ Evacuation with } & \multicolumn{2}{|r|}{ Stool } & \multirow{2}{*}{ Evacuations per week } & \multirow{2}{*}{ Diagnostic of constipation } \\
\hline & Pain & Difficulty & Consistency & Form & & \\
\hline 1 & Yes & Yes & Hard & Scybalous & 7 & yes \\
\hline 2 & No & Yes & Pasty & Amorphous & 7 & yes, controlled \\
\hline 3 & Yes & Yes & Hard & Scybalous & 7 & yes \\
\hline 4 & Yes & Yes & Hard & Large pellet-like & 14 & yes \\
\hline 5 & No & Yes & Hard & Scybalous & 7 & yes \\
\hline 6 & Yes & Yes & Hard & Scybalous & 0.5 & yes \\
\hline 7 & Yes & Yes & Pasty & Cylindrical with or without cracks & 7 & no \\
\hline 8 & Yes & Yes & Hard & Scybalous & 2.5 & yes \\
\hline 9 & No & Yes & Hard to pasty & Scybalous and thick cylindrical & 7 & yes, controlled \\
\hline 10 & Yes & Yes & Hard & Scybalous & 3.5 & yes \\
\hline 11 & Does not know & Yes & Hard & Large-pellet like & 3.5 & yes \\
\hline 12 & No & No & Pasty & Does not know & 3.5 & no \\
\hline 13 & No & Yes & Hard & Scybalous & 7 & yes \\
\hline 14 & Yes & Yes & Hard & Thick and cylindrical & 2 & yes \\
\hline 15 & No & No & Pasty & Large-pellet like & 7 & no \\
\hline 16 & No & No & Pasty & Amorphous & 3.5 & no \\
\hline 17 & No & Yes & Pasty & Amorphous & 7 & no \\
\hline 18 & Yes & Yes & Hard & Scybalous & 14 & yes \\
\hline 19 & Yes & Yes & Hard & & 3.5 & yes \\
\hline 20 & Yes & Yes & Hard & Scybalous & 7 & yes \\
\hline 21 & Yes & Yes & Hard & Scybalous & 2.5 & yes \\
\hline 22 & Yes & Yes & Hard & Scybalous & 1 & yes \\
\hline 23 & Yes & Yes & Hard & Scybalous & 1 & yes \\
\hline 24 & No & Yes & Pasty & Amorphous & 2 & yes \\
\hline 25 & No & No & Hard & Scybalous & 7 & yes \\
\hline 26 & No & Yes & Hard & Scybalous & 7 & yes \\
\hline 27 & No & Yes & Hard & Cylindrical with cracks & 2.5 & yes \\
\hline
\end{tabular}


intestinal habit compatible with constipation. Two (7.4\%) had under control constipation, as they had been receiving treatment for constipation and were not constipated at the time of the study, and $5(18.5 \%)$ presented normal intestinal habit. Out of the 22 patients with constipation, $6(27 \%)$ were not receiving any type of treatment at the time of the study, $4(18 \%)$ were treated with diet only, 5 (23\%) were receiving laxatives, and 6 (27\%) used suppository or sorbitol solution. One patient was under oral medication with mineral oil.

Median (and 25th and 75th percentiles) fiber intake of the 22 patients with constipation $(61.0 \% ; 32.2$ and 84.7$)$ was not statistically lower than the intake of the 5 patients without constipation $(61.0 \% ; 46.2$ and 84.7 ; $P=0.659$, MannWhitney test).

Out of the total 27 patients, 24 had their hemoglobin measured and $6(25 \%)$ were anemic.

\section{DISCUSSION}

In this study on the nutritional status of individuals with RS, we have assessed 27 patients with typical clinical manifestation, diagnosed according to the modified ${ }^{(28)}$ HAGBERG et al. ${ }^{(7)}$ criteria. Samples of other studies that performed anthropometric assessment of RS individuals consisted of 10 to a maximum of 21 patients $^{(6,8,13,14,29)}$. It is worth noticing that this large number, compared to the literature, was made possible owing to the help of the Brazilian Rett Syndrome Association and neuropediatricians of São Paulo city, who allowed their patients to take part in this study.

Given the progressive character of the disease, the age of the 15 patients $(56 \%)$ on stage III was lower than the age of the 12 patients $(44 \%)$ on stage IV. Twenty-two $(81.5 \%)$ out of the total 27 patients were receiving, at least, one medication, more commonly anticonvulsants. It has been also observed that 22 patients $(81.5 \%)$ had been hospitalized in the past.

Low height-for-age (<-2.0 standard-deviation) was diagnosed in $48.1 \%$ of the girls. Direct comparison of these results with the literature is difficult because not every author adopts the same anthropometric criteria. In any case, all other studies have found linear growth deficit in $48 \%$ to $70 \%$ of their samples ${ }^{(6,8,13,29)}$. As for weight, 10 patients $(37.0 \%)$ from this study had deficits, and $3(11.1 \%)$ were overweight. In other studies, weight-for-height deficits have been observed in $50 \%$ to $60 \%$ of the patients ${ }^{(6,29)}$, adopting a less rigorous cut-off point than in this study.

The existence of anthropometric deficits in RS has been confirmed, and height-for-age deficits prevailed in this study. On the other hand, overweight was also observed in three patients (11.1\%). It is worth mentioning that the skinfold thickness of these three patients was compatible with obesity (data not shown).

Chewing and swallowing problems seem to be one of the factors that contribute, at least in part, to the anthropometric deficits observed in $\mathrm{RS}^{(14)}$. Our results have shown that almost all $(26 / 27)$ of the patients were dependent to feed. Six parents $(15.4 \%)$ perceived their daughters as not having any chewing and swallowing problems, even though none of these girls was able to eat solid foods. Our findings are compatible with other studies $^{(13,14,19,29)}$. It seems that oral motor deficits may worsen nutritional status by decreasing energy intake ${ }^{(14,30)}$.

In our study, energy intake was assessed using different criteria because the anthropometric deficits observed could make the expression in relation to the chronological age not represent properly the needs of these individuals.

In this regard, the analysis in relation to the chronological age resulted in a median intake of $72.3 \%$ of the expected value for age, a number statistically lower than the median energy intake expressed compared to the expected weight $(111.0 \%)$, and the expected weight for height (106.6\%). Our results, such as those from the literature, have shown insufficient median intake for chronological age. Nevertheless, in our opinion, the median expressed in relation to the expected weight for observed height would be more useful information, because this would be the amount of energy intake expected to allow nutritional recovery of these patients.

The majority of patients in our study presented adequate calorie intake, despite their dependence to feed and their chewing and swallowing difficulties. As for qualitative analysis in relation to the macronutrients, they presented proteins, carbohydrates and lipids proportions within the accepted ranges (except one patient, who was receiving ketogenic diet).

Some nutrient intakes, such as calcium and iron must be discussed. Sixty-three per cent of the patients did not meet $80 \%$ of the recommendations for iron, with the lowest intake being observed in patients on stage IV, although the difference was not statistically significant, as observed on Table 2 . We should stress that iron deficiency anemia prevalence in our population was $25.0 \%$. On the one hand, this may be caused by an insufficient intake of iron with high bioavailability found in red meat (remember the swallowing difficulties and the lower intake of proteins by patients on stage IV compared to patients on stage III). On the other hand, diets poor in iron and iron deficiency anemia is a problem also observed in normal children and adolescents of São Paulo(26).

Regarding calcium, insufficient intake was observed in 55.6\% of the patients, with lower median adequacy in patients on stage IV (Table 2). This data may reflect a lower intake of milk and dairy products among older patients. An assumption that could lead to further studies is the increase in the proportion of patients with lower lactose absorption as they get older.

Generally speaking, these patients with RS, despite the chewing and swallowing difficulties, presented, in our opinion, adequate median energy intake, with deficits of iron, calcium, vitamin A and vitamin $\mathrm{C}$ intakes. This information might be used to guide food and vitamin/mineral supplementation recommendations. It has also been observed that $77.8 \%$ of the patients presented fiber intakes bellow the minimum recommendation (age +5$)$.

It is worth noticing the high prevalence of constipation $(81.5 \%$; $22 / 27$ ) in this group. This result clearly depends on the criteria used to classify constipation in children and adolescents, and so far, there has been no consensus ${ }^{(11)}$, but it is unquestionable that constipation is a problem in RS. Median fiber intakes were similar among the patients with and without constipation. It should be pointed out that only two patients were classified as having 
controlled constipation, which could indicate that the problem was not being treated, the treatment was not adequate, or even that the patients presented refractory constipation ${ }^{(1,19)}$.

In conclusion, our study shows high occurrence of nutritional problems and chronic constipation, all of which should be considered on the multiprofessional therapeutic planning of patients with Rett syndrome.

\section{ACKNOWLEDGMENTS}

We would like to thank Silvana Santos, President of The Brazilian Rett Syndrome Association and the Neuropediatricians Prof. Dr. Fernando Kok, Prof. Dr. Sérgio Rosemberg and Dra. Cristina Maria Pozzi for the referral and/or diagnostic evaluation of the patients included in this study.

Schwartzman F, Vítolo MR, Schwartzman JS, Morais MB. Práticas alimentares, estado nutricional e constipação intestinal na síndrome de Rett. Arq Gastroenterol. 2008;45(4):284-9.

RESUMO - Racional - Distúrbios na mastigação, deglutição e motilidade digestiva podem predispor pacientes com síndrome de Rett à ocorrência de anormalidades nutricionais. Objetivos - Avaliar as práticas alimentares, o estado nutricional e a prevalência de constipação na síndrome de Rett clássica. Métodos - Estudaramse 27 pacientes do sexo feminino, com idade entre 2,6 e 21,8 anos. Avaliaram-se os seguintes parâmetros: registros alimentares, peso, estatura, características do hábito intestinal. Peso e estatura foram comparados com os valores do Centro Nacional para Estatísticas da Saúde (EUA). Resultados - Incapacidade para ingerir alimentos sólidos foi observada em $80,8 \%$ das pacientes. Déficit de estatura foi observado em 13 (48,1\%) meninas, sendo mais intenso nas pacientes no estágio IV. Déficit de estatura para a idade foi observado em 13 (48,1\%) pacientes. Em 10 (37,0\%) pacientes encontrou-se déficit de peso para a estatura, $15(55,6 \%)$ apresentaram peso normal e duas $(7,4 \%)$ sobrepeso para a estatura. A ingestão mediana de energia, segundo o peso para a estatura foi igual a $106,6 \%$. Ingestão insuficiente de ferro foi observada em $63 \%$ e de cálcio em $55,6 \%$ das pacientes. Constipação foi verificada em $74,1 \%$ das pacientes e não apresentou relação com a quantidade de fibra alimentar na dieta. Conclusão - Observou-se elevada ocorrência de problemas nutricionais e de constipação intestinal, que devem ser considerados no planejamento terapêutico multidisciplinar destinado às pacientes com síndrome de Rett.

DESCRITORES - Síndrome de Rett. Estado nutricional. Transtornos de deglutição. Constipação intestinal.

\section{REFERENCES}

1. Braddock SR, Braddock BA, Graham JM Jr. Rett syndrome. An update and review for the primary pediatrician. Clin Pediatr (Phila). 1993;32:613-26.

2. Budden SS. Management of Rett syndrome: a ten year experience. Neuropediatrics. 1995;26:75-7.

3. Centro de Informática da Saúde. Universidade Federal de São Paulo - Escola Paulista de Medicina. Sistema de Apoio à Nutrição, versão 2.5 a. 1994.

4. Ekvall SW. Constipation and fiber. In: Ekvall SH, editor. Pediatric nutrition in chronic diseases and developmental disorders: prevention, assessment, and treatment. New York: Oxford University Press; 1993. p.301-9.

5. Freudenheim JL. A review of study designs and methods of dietary assessment in nutritional epidemiology of chronic disease. J Nutr. 1993;123:401-5.

6. Haas RH, Dixon SD, Sartoris DJ, Hennessy MJ. Osteopenia in Rett sindrome. J Pediatr. 1997;131:771-4

7. Hagberg B, Aicardi J, Dias K, Ramos O. A progressive syndrome of autism, dementia, ataxia, and loss of purposeful hand use in girls: Rett's syndrome: report of 35 cases. Ann Neurol. 1983;14:471-9.

8. Holm VA. Physical growth and development in patients with Rett syndrome. Am J Med Genet. 1986;24:119-26.

9. Jelliffe DB. Evaluación del estado nutricional de la comunidad. Genebra: OMS Organización Mundial de la Salud; 1968. 191p. (Serie de Monografias, 53).

10. Krebs-Smith SM, Clark LD. Validation of a nutrient adequacy score for use with women and children. J Am Diet Assoc. 1989;89:775-83.

11. Maffei HV, Morais MB. Defining constipation in childhood and adolescence: from Rome, via Boston, to Paris and ...? J Pediatr Gastroenterol Nutr. 2005;41:485-6.

12. Morais MB, Vítolo MR, Aguirre ANC, Fagundes-Neto U. Measurement of low dietary fiber intake as a risk factor for chronic constipation in children. J Pediatr Gastroenterol Nutr. 1999;29:132-5.

13. Morton RE, Bonas R, Minford J, Kerr A, Ellis RE. Feeding ability in Rett syndrome. Dev Med Child Neurol. 1997;39:331-5.

14. Motil KJ, Schultz RJ, Wong WW, Glaze DG. Increased energy expenditure associated with repetitive involuntary movement does not contribute to growth failure in girls with Rett syndrome. J Pediatr. 1998;132:228-33.

15. Motil KJ, Schultz RJ, Browning K, Trautwein L, Glaze DG. Oropharyngeal dysfunction and gastroesophageal dismotility are present in girls and women with Rett syndrome. J Pediatr Gastroenterol Nutr. 1999;29:31-7.

16. Must A, Dallal GE, Dietz WH. Reference data for obesity: 85 th and 95 th percentiles of body mass index $\left(\mathrm{wt} / \mathrm{ht}^{2}\right)$ and triceps skinfold thickness. Am J Clin Nutr. 1991;53:839-46.
17. National Research Council (NRC). Recommended dietary allowances. $10^{\text {th }} \mathrm{ed}$. Washington: National Academy Press; 1989.

18. Pinheiro ABV, Lacerda EMA, Benzecry EH, Gomes MCS, Costa VM. Tabela para avaliação de consumo alimentar em medidas caseiras. $4^{\mathrm{a}}$ ed. Rio de Janeiro: Produção Independente; 1998.

19. Santos S, Sá AM, Dagnesi MD, Neves DS, Maleita PM, Andrade RL, Marchioni SA Galli VL, Schwartzman JS. O perfil da portadora de síndrome de Rett no Brasil. Temas Desenvolv. 1999;8:6-12.

20. Schultz RJ, Glaze DG, Motil KJ, Armstrong DD, del Junco DJ, Hubbard CR, Percy AK The pattern of growth failure in Rett syndrome. Am J Dis Child. 1993;147:633-7.

21. Schwartzman JS. Síndrome de Rett. Rev Bras Psiquiatr. 2003;25:110-3.

22. Segawa M, Nomura Y. Rett syndrome. Curr Opin Neurol. 2005;18:97-104.

23. Shils M, Olson S, Shike M. Modern nutrition in health and diseases. 8th ed Philadelphia: Lea \& Febiger; 1994:A92-8.

24. Sullivan PB. Gastrointestinal problems in the neurologically impaired child. Baillieres Clin Gastroenterol. 1997;11:529-46.

25. Szarfarc S, Souza SB. Prevalence and risk factors in iron deficiency and anemia. Arch Latinoam Nutr. 1997;47(2 Suppl 1):35-8.

26. Tanner JM. Growth at adolescence. 2nded. Oxford: Blackwell Scientific Publishers; 1962.

27. The Rett Syndrome Diagnostic Criteria Work Group. Diagnostic criteria for Rett syndrome. Ann Neurol. 1988;23:425-8.

28. Stevenson RD. Use of segmental measures to estimate stature in children with cerebral palsy. Arch Pediatr Adolesc Med. 1995;149:658-62.

29. Thommessen M, Kase BF, Riis G, Heiberg A. The impact of feeding problems on growth and energy intake in children with cerebral palsy. Eur J Clin Nutr. 1991;45:479-87.

30. Thommessen M, Kase BF, Heiberg A. Growth and nutrition in 10 girls with Rett syndrome. Acta Paediatr. 1992;81:686-90.

31. Williams CL, Bollella M, Wynder EL. A new recommendation for dietary fiber in childhood. Pediatrics. 1995;96(5 Pt 2):985-8.

32. WHO World Health Organization. Nutritional anaemias. Geneva: WHO; 1972. 29p (WHO Technical Report Series, 503).

33. WHO World Health Organization. Physical status: the use and interpretation of anthropometry. Geneva: WHO; 1995. 452p. (WHO Technical Report Series, 854).

34. Yates AA, Schlicker SA, Suitor CW. Dietary reference intakes: the new basis for recommendations for calcium and related nutrients, B vitamins, and choline. J Am Diet Assoc. 1998;98:699-706. 